\title{
QUALITY OF SILAGES MADE FROM MEADOW SWARD FROM SOUTH-EASTERN POLAND
}

\begin{abstract}
Weather conditions prevailing in Poland often cause that meadow sward designated for silage is harvested too late, which decreases the quality of prepared silage. The aim of the research was to assess the quality of silages from dried meadow sward. The silages were ensiled in large cylindrical bales in selected individual farms specializing in milk production. The farms where the research was carried out were located in three voivodeships: slaskie, malopolskie and podkarpackie. In the prepared plant material, the basic chemical composition was determined using the method. When comparing the mean values, it was established that silages from the investigated region had a favourable content of total protein, the highest concentration was recorded for silages from Slask, followed by Malopolska and Podkarpacie. A slightly elevated concentration of crude fibre, fraction of acid detergent fibre (ADF) and neutral detergent fibre (NDF), was recorded. This fact shows that farmers collect raw material, particularly from the first cut, too late. Nutrient value of silages from meadow sward decreases with progressing vegetation. Higher protein and energy losses during sward ensiling were also observed at considerable drying of the plant material. In most cases, silages from the studied farms had a low content of monosaccharides. The carried out chemical analyses showed that in overall assessment the studied silages are of good quality; silages prepared from meadow sward from the third cut had the highest value. Proper technology of preservation of meadow sward is one of important factors in the production of feed for ruminants.
\end{abstract}

Keywords: fermentation, voivodeships, correlation, organic components, lactic acid, dry matter

\section{Introduction}

In European countries like the Netherlands, Germany or Denmark, silage is a highly valued feed used in feeding ruminants. Ensiling is a preservation of moist forage crops under anaerobic conditions in order to improve the nutrient content. As a result, $\mathrm{pH}$ decreases and the moist forage is preserved from spoilage microorganisms. This is a safe and easy-to-use technique; it causes no pollution to the environment, and the products are regarded as natural $[1,2]$. Adequate preservation technology is a very important factor in the production of feeds for ruminants. Quality of silages depends on numerous factors, such as the type of ensiled raw material, drying and proper compaction of matter, and also on proper silo sealing or heap sealing and proper storage. Proper course of the ensiling process requires appropriate concentration of dry matter (d.m.) in the starting material, namely

\footnotetext{
${ }^{1}$ Institute of Plant Production, Department of Grassland Management, University of Agriculture in Kraków, Kraków, Poland, ORCID: 0000-0002-3146-6212

${ }^{2}$ Department of Cattle Breeding, National Research Institute of Animal Production, Balice, Poland, ORCID: 0000-0002-8780-1585

${ }^{3}$ Department of Mathematical and Statistical Methods, Poznań University of Life Sciences, Poznań, Poland, phone +48 61 8487143, ORCID: 0000-0002-0102-0084

* Corresponding author: jan.bocianowski@up.poznan.pl
} 
$250-400 \mathrm{~g} / \mathrm{kg}$. The material for ensiling should also have a high concentration of water-soluble carbohydrates (WSC) and a low buffering capacity [3]. Higher residual WSC content suggests lower d.m. losses during fermentation and produces better silage. In terms of chemical processing, parameters related to the ensiling/fermentation process (for example temperature, air content, chopped length of forages, fermentation period, moisture content and $\mathrm{pH}$ ) must also be taken into consideration [2]. Preservation of forage crops as silage depends on the production of sufficient acid to inhibit the activity of undesirable microorganisms under anaerobic conditions. Bacteria inoculated during ensiling dominate epiphytic bacteria in the forage and allow for successful reduction of $\mathrm{pH}$, thus reducing losses in yield and nutritive value associated with silage production [4]. The quality of grass silage and haylage varies depending on the used agricultural techniques, silage technology, weather conditions, but phyto phenological maturity of the meadows when mowing has the most significant impact. The main factors that influence the quality of silage and haylage with postponing the deadline of grass mowing for silage mass include chemical composition, fermentation quality, ad libitum intake and digestibility [5]. Studies indicate that there is a relationship between the amount of dry matter and the course of the fermentation process [6]. Therefore, in the case of ensiling meadow sward plants, it is most common to use wilted or dried up plants in which water content ranges from 40 to $50 \%$ [7]. Compared to fresh plants, ensiling wilted plants limits nutrient losses by, on average, $50 \%$. When plants are too wet, ensiling them leads to spilling of silage juice, and thereby to nutrient losses. Ensiling properly dried up meadow sward with increased dry matter content causes an increase in silage $\mathrm{pH}$, has a positive effect on the ratio of the amount of lactic acid to other acids and on the decrease of fermentation losses [8]. The aim of this research was to determine the nutrient content in silages from selected farms of south-eastern Poland, prepared from meadow plants at three harvest times.

\section{Material and methods}

The research was carried out in individual agricultural farms located in three voivodeships: slaskie, malopolskie and podkarpackie, in the years 2015-2017. The farms were random chosen from farms about comparable areas and the similar utilize methods. All farms were specialized in dairy cattle production, where silages are the basis for feeding. The silages under study were prepared from meadow sward and came from three different harvest dates (three cuts). The first harvest took place at the stage of heading of dominant grass species, the second about seven weeks later, and the third after the next eight weeks.

\section{Characteristics of permanent grasslands in the studied farms}

Slaskie voivodeship. Grasslands were located on acid podzolic soil $\left(\mathrm{pH}_{\mathrm{KCl}}\right.$ was 4.6), which belongs to soil quality class IV, V, with different content of phosphorus and potassium, i.e. from medium to high. The following prevailed in plant communities covering the grasslands: perennial ryegrass (Lolium perenne L.), meadow fescue (Festuca pratensis L.), cock's-foot (Dactylis glomerata L.), timothy grass (Phleum pratense L.), tall fescue (Festuca arundinacea Schreb.) and common meadow grass (Poa pratensis L.) with a slight share in the sward of dicotyledons. The share of grass species equalled $70 \%$, legumes accounted for about $2 \%$ and herbs and weeds for $28 \%$. The investigated agricultural lands are permanently sodded meadows used for hay. 
Malopolskie voivodeship. Grasslands were located on brown soil with granulometric composition of loamy sand, with $\mathrm{pH}_{\mathrm{KCl}} 4.1$ and a medium phosphorus content and a low potassium content. Cock's-foot (Dactylis glomerata L.), red fescue (Festuca rubra L.) and common meadow grass (Poa pratensis L.) with a large share in the sward of dicotyledons were dominant in the plant community. Grass fraction encompassed about $65 \%$ of species, legumes about $12 \%$ and herbs and weeds about $23 \%$. They were permanently sodded areas and used in the mown-grazed way. The investigated silage was made from plants from three harvest dates.

Podkarpackie voivodeship. Brown soils originating from flysch rocks occurred on the investigated farms, with $\mathrm{pH}_{\mathrm{KCl}}=4.2$. The factor reducing the quality of soils in this region the most is their excessive acidification. Approximately one-third of the soil area have acid or slightly acid reaction. Available phosphorus content is very low or low, potassium content - varied, from medium to high, and magnesium content - very high. The following were dominant in the meadow community: common meadow grass (Poa pratensis L.), meadow fescue (Festuca pratensis L.), cock's-foot (Dactylis glomerata L.), meadow soft grass (Holcus lanatus FG.); herbs and weeds, mainly common dandelion (Taraxacum officinale F.H. Wigg.), had a substantial share. Grass species accounted for $64 \%$, legumes for only $3 \%$ and herbs and weeds for $33 \%$.

In all the studied communities there were legumes, particularly red clover (Trifolium pratense L.) and white clover (Trifolium repens L.), and in some communities - common bird's-foot trefoil (Lotus corniculatus L.). The technology of harvesting the raw material for silage was similar in all the studied farms. A two-stage harvest was applied: first, green forage was cut with a rotary mower, and then it was dried; depending on the course of weather conditions, it took from 1 to 4 days. Raking was done half an hour before harvest. Raw material was gathered using a fixed chamber round baler, and the bales were transported to the storage site. The bales were then wrapped with four layers of self-adhesive polyethylene foil $(0.025-0.030 \mathrm{~mm}$ thick and $500 \mathrm{~mm}$ wide). The time from forming a bale to securing it with the foil was maximum $4 \mathrm{~h}$. Before feeding on silage, samples were collected for chemical analysis. In those samples, the content of basic components was determined with the Weende method, $\mathrm{pH}$ - using a stationary $\mathrm{pH}$ meter TOLEDO MA 235, and the ammonia level - with Conway's method. The content of lactic acid was determined using a gas chromatograph Varian 3400 CX, FID (flame ion) detector, $\mathrm{J} \& W$ Scientific DB-FFAP column (30 $\mathrm{m}$ long, $0.53 \mathrm{~mm}$ in diameter), carrier gas argon, feeder temperature $200{ }^{\circ} \mathrm{C}$, detector temperature $240{ }^{\circ} \mathrm{C}$, column temperature $60-210{ }^{\circ} \mathrm{C}$. The content of acetic acid and butyric acid was determined using a liquid chromatograph INGOS LCP 5020, steel column 8×250 mm filled with OSTION LG-KS 0800 H+ (Tessek), mobile phase: $5 \mathrm{mM} \mathrm{H}_{2} \mathrm{SO}_{4}$.

\section{Statistical analysis}

Firstly, the normality of the distributions of all the studied traits was tested using Shapiro-Wilk's normality test [9]. Two-way analysis of variance was conducted to determine the effects of cut, voivodeship and cut $\times$ voivodeship interaction on the variability of observed traits. The Fisher's least significant differences ( $L S D$ s) were determined at the significance level 0.05. The relationships between observed traits were assessed based on Pearson's correlation coefficients using FCORRELATION procedure in GenStat (version 18.2). Presentation of the results is limited to providing mean values of studied years. 


\section{Results}

Results of analysis of variance indicated that the main effects of cut were significant for $\mathrm{pH}$, protein and fibre; main effects of voivodeship were significant for $\mathrm{pH}$, crude ash, WSC, NDF, crude fibre and dry matter (Table 1). Cut $\times$ voivodeship interaction was statistically significant only for fibre (Table 1). Data about the content of the nutrients determined in silages are presented in Figures 1 and 2. Dry matter content in the studied silages varied from 239.7 to $745.5 \mathrm{~g} / \mathrm{kg} \mathrm{d} . \mathrm{m}$. The average dry mass content in silages obtained in podkarpackie voivodeship was $395.1 \mathrm{~g} / \mathrm{kg} \mathrm{d.m.,} \mathrm{in} \mathrm{malopolskie} \mathrm{-} 469.4 \mathrm{~g} / \mathrm{kg}$ d.m., and in silages from slaskie voivodeship it was $363.9 \mathrm{~g} / \mathrm{kg} \mathrm{d} . \mathrm{m}$. Total protein content in the silages under assessment ranged from 58.4 to $241.8 \mathrm{~g} / \mathrm{kg} \mathrm{d.m}$. The lowest total protein content was obtained in silages from meadow sward from farms located in malopolskie voivodeship (the mean of all samples was $139.8 \mathrm{~g} / \mathrm{kg} \mathrm{d.m}$.), followed by podkarpackie voivodeship (141.1 g/kg d.m.), and the highest average concentration of this nutrient was observed in silages from meadow sward from slaskie voivodeship (159.9 g/kg d.m.).

Table 1

Mean square from a two-way analysis of variance for observed traits

\begin{tabular}{|c|c|c|c|c|}
\hline Source of variation & Cut & Voivodeship & Cut $\times$ voivodeship & Residual \\
\hline Degrees of freedom & 2 & 2 & 4 & 74 \\
\hline pH & $0.643^{*}$ & $1.936^{* * *}$ & 0.195 & 0.199 \\
\hline Crude ash & 467.5 & $4,689^{* * *}$ & 143.5 & 302.7 \\
\hline Crude protein & $3,797^{*}$ & 2,812 & 2,461 & 1,143 \\
\hline Crude fat & 100.2 & 37.46 & 12.14 & 38.23 \\
\hline WSC & 257.4 & $4,882^{* *}$ & 997.3 & 767.3 \\
\hline ADF & 1,910 & 7,049 & 825 & 2,341 \\
\hline NDF & 781 & $28,409^{* *}$ & 6,514 & 3,807 \\
\hline ADL & 147.9 & 520.7 & 217 & 279.4 \\
\hline Crude fibre & $3,715^{* * *}$ & $2,965^{* * *}$ & $530.5^{*}$ & 200.4 \\
\hline Ammonia & 134.6 & 79.00 & 56.7 & 108.9 \\
\hline Lactic acid & 78.64 & 3.150 & 72.03 & 88.96 \\
\hline Acetic acid & 53.82 & 34.79 & 13.85 & 35.34 \\
\hline Dry matter & 5,068 & $62,128^{* *}$ & 2,257 & 11,342 \\
\hline
\end{tabular}

When analysing crude fibre content in ready-to-feed silages, it was established that its content in individual variants ranged from 258.0 to $350.6 \mathrm{~g} / \mathrm{kg} \mathrm{d} . \mathrm{m}$. and was the highest in silage from podkarpackie voivodeship. Crude fat content in the studied silages ranged between $16.2 \mathrm{~g} / \mathrm{kg} \mathrm{d.m}$. in the silage from podkarpackie voivodeship and $45.2 \mathrm{~g} / \mathrm{kg} \mathrm{d} . \mathrm{m}$. in silages from slaskie voivodeship. Content of water-soluble WSCs in the feeds under investigation was more varied than protein and fat content. In general, silages from malopolskie voivodeship were richer in carbohydrates, the average content of this nutrients being $68.0 \mathrm{~g} / \mathrm{kg} \mathrm{d.m.;} \mathrm{silages} \mathrm{from} \mathrm{podkarpackie} \mathrm{had} 47.2 \mathrm{~g} / \mathrm{kg} \mathrm{d.m.;} \mathrm{and} \mathrm{from} \mathrm{slaskie} \mathrm{-} \mathrm{only}$ $38.5 \mathrm{~g} / \mathrm{kg}$ d.m. Content of lactic acid, the most desirable in silages, ranged from 1.0 to $45.3 \mathrm{~g} / \mathrm{kg}$ d.m. Acetic acid content was variable, ranging from 0.6 to $28.3 \mathrm{~g} / \mathrm{kg}$ d.m. By contrast, butyric acid, which lowers the final estimate of silage quality, was not present in any silage. 

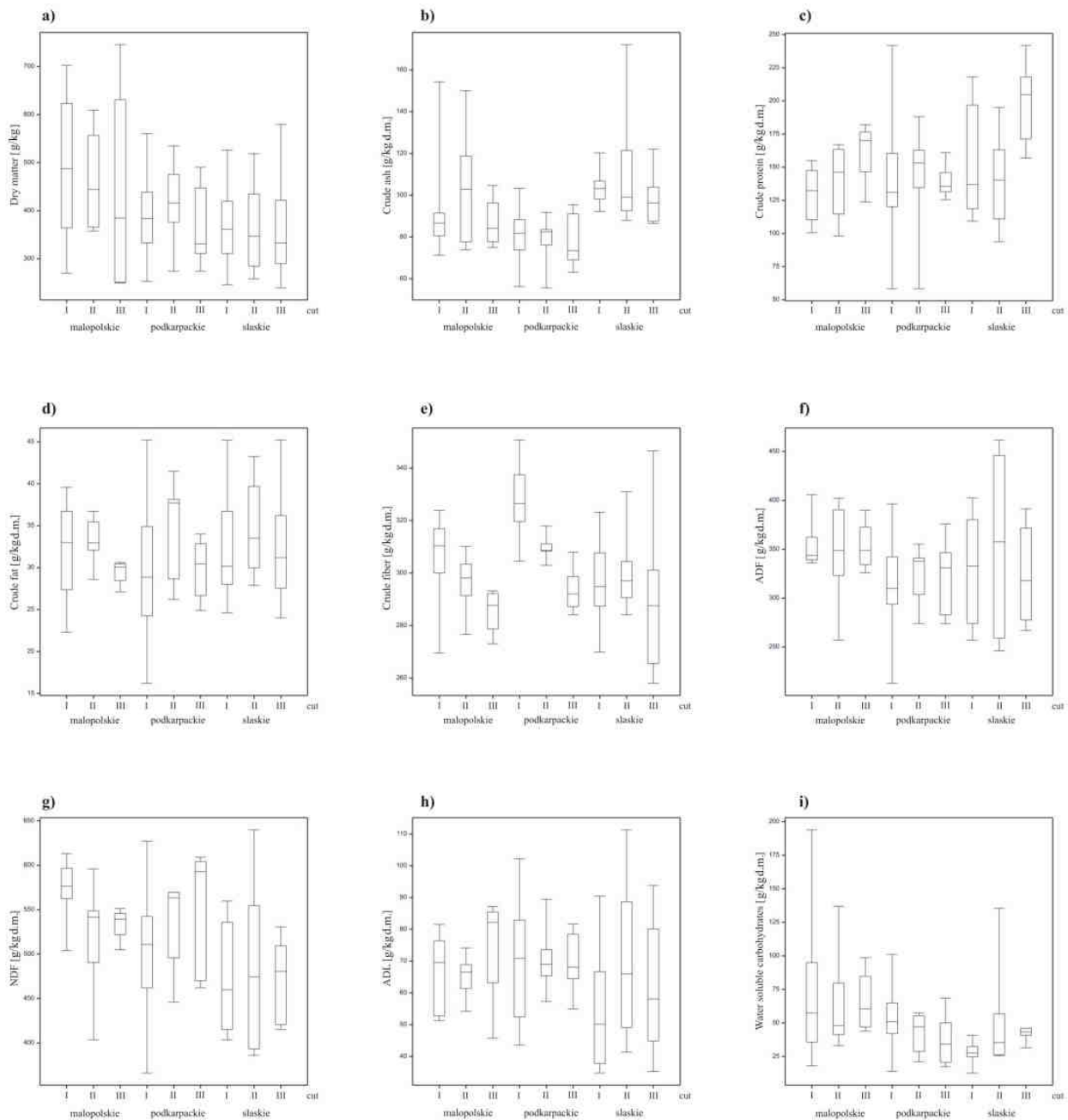

Fig. 1. Boxplot of: a) dry matter, b) crude ash, c) total protein, d) crude fat, e) crude fibre, f) ADF, g) NDF, h) ADL and i) water-soluble carbohydrates in three cuts and three voivodeships. The bottom and top of the box are the 25th and 75th percentile - the lower and upper quartiles, respectively, and the band near the middle of the box is the 50th percentile - the median. The whisker ends represent the minimum and maximum of all the data. ( $L S D_{0.05}$ for dry matter: 116.2, crude ash: 18.99 , total protein: 36.9 , crude fat: 6.748 , crude fibre: 15.45 , ADF: 52.8 , NDF: 67.34, ADL: 18.24 and water-soluble carbohydrates: 30.23 )

Positive correlations were observed between: $\mathrm{pH}$ and crude ash, $\mathrm{pH}$ and fat, $\mathrm{pH}$ and WSC, $\mathrm{pH}$ and acid detergent fibre (ADF), $\mathrm{pH}$ and dry matter, crude ash and ADF, crude ash and lactic acid, WSC and ADF, WSC and neutral detergent fibre (NDF), WSC and dry matter, ADF and NDF, ADF and ADL, ADF and dry matter, NDF and ADL, NDF and dry matter, ADL and dry matter (Table 2). Negative correlation coefficients were obtained for: $\mathrm{pH}$ and ammonia, $\mathrm{pH}$ and acetic acid, crude ash and ammonia, protein and WSC, fat and 
NDF, WSC and acetic acid, ADF and ammonia, ADF and acetic acid, ammonia and dry matter, acetic acid and dry matter (Table 2).
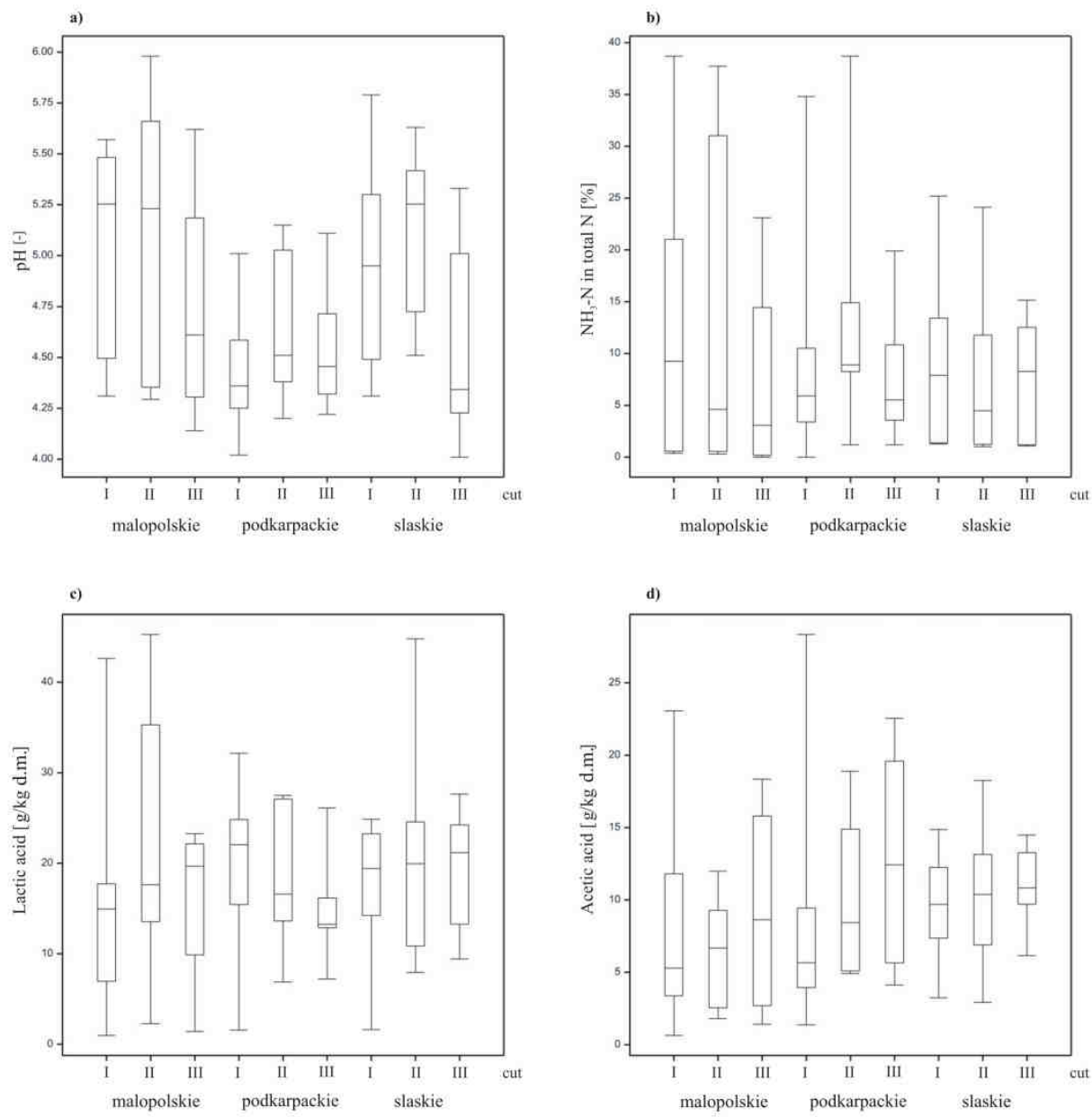

Fig. 2. Boxplot of: a) pH, b) ammonia, c) lactic acid and d) acetic acid in three cuts and three voivodeships ( $L S D_{0.05}$ for $\mathrm{pH}$ : 0.487 , ammonia: 11.37 , lactic acid: 10.29 and acetic acid: 6.487$)$

\section{Discussion}

Dry matter content in green fodders should be approximately $160-240 \mathrm{~g} / \mathrm{kg} \mathrm{d.m}$., whereas in silages from dried grasses $-300-400 \mathrm{~g} / \mathrm{kg} \mathrm{d.m}$. [10]. Dry matter content in the raw material being ensiled, obtained from meadow flora, should be from 350 to $400 \mathrm{~g} / \mathrm{kg}$ d.m. By contrast, Haigh $[11,12]$ states that the optimal content of dry matter should be $350 \mathrm{~g} / \mathrm{kg}$ d.m. because content below $250 \mathrm{~g} / \mathrm{kg}$ d.m. induces a risk of spilling of silage juices from bales. In the case of too high dry matter content in the raw material, there are 
difficulties with proper silage compaction, there is a risk of unwanted aerobic conditions, silage heating up, molds and mycotoxins. In addition, raw material below $250 \mathrm{~g} / \mathrm{kg} \mathrm{d} . \mathrm{m}$. should not be ensiled since there is a risk of proliferation of bacteria of the genus Clostridium and formation of undesirable butyric acid.

Table 2

Correlation coefficients between observed traits

\begin{tabular}{|c|c|c|c|c|c|c|c|c|c|c|c|c|}
\hline Traits & 폼 & 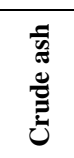 & 吾 & 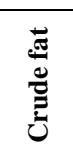 & $U_{n}^{\infty}$ & $\frac{\pi}{4}$ & $\mathrm{z}$ & $\overline{\mathrm{Z}}$ & 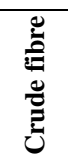 & 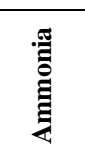 & 苾 & 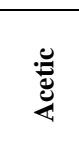 \\
\hline Crude ash & $0.38^{* * *}$ & & & & & & & & & & & \\
\hline Crude protein & -0.05 & 0.06 & & & & & & & & & & \\
\hline Crude fat & $0.22^{*}$ & 0.12 & 0.19 & & & & & & & & & \\
\hline WSC & $0.27^{*}$ & -0.06 & $-0.30^{* * *}$ & -0.12 & & & & & & & & \\
\hline $\mathrm{ADF}$ & $0.40^{2 * \pi * \pi}$ & $0.30^{* *}$ & -0.12 & -0.21 & $0.35^{* *}$ & & & & & & & \\
\hline NDF & 0.05 & -0.18 & -0.20 & $-0.27^{*}$ & 0.22 & $0.65^{* * * *}$ & & & & & & \\
\hline ADL & 0.11 & -0.16 & -0.14 & -0.21 & 0.17 & $0.26^{*}$ & 0.09 & & & & & \\
\hline Crude fibre & -0.20 & -0.15 & -0.15 & -0.10 & -0.07 & -0.07 & 0.00 & 0.17 & & & & \\
\hline Ammonia & $-0.36^{* * 4}$ & $-0.27^{*}$ & 0.13 & 0.16 & -0.16 & $-0.31^{* * 4}$ & -0.04 & -0.22 & 0.02 & & & \\
\hline Lactic & -0.08 & $0.32^{* *}$ & 0.12 & 0.11 & -0.17 & 0.06 & -0.01 & -0.15 & 0.00 & -0.05 & & \\
\hline Acetic & $-0.23^{*}$ & 0.06 & 0.10 & 0.07 & $-0.66^{* * \pi}$ & $-0.26^{*}$ & -0.09 & -0.03 & -0.16 & 0.06 & 0.03 & \\
\hline Dry matter & $0.45^{* * * *}$ & 0.06 & -0.14 & 0.02 & $0.71^{* * * *}$ & $0.44^{* * * *}$ & $0.24^{*}$ & $0.26^{*}$ & 0.04 & $-0.23^{*}$ & -0.10 & $-0.7^{\prime}$ \\
\hline
\end{tabular}

The observed beneficial changes in total protein content of the silages under evaluation are attributed to the presence of legumes in the sward. Luscher et al. [13], when studying silages from meadow plants with a varied share of red clover, observed benefits from increased share of legumes in the sward. Simic et al. [14] also observed a higher share of total protein in silage with an approximately $30 \%$ share of red clover in meadow sward compared to silage from the control. Feeds from grasslands used in feeding ruminants should contain approximately $200-250 \mathrm{~g} / \mathrm{kg}$ d.m. crude fibre and should not exceed $280 \mathrm{~g} / \mathrm{kg} \mathrm{d.m.} \mathrm{[15].} \mathrm{In} \mathrm{this} \mathrm{respect,} \mathrm{only} \mathrm{a} \mathrm{part} \mathrm{of} \mathrm{silages} \mathrm{from} \mathrm{the} \mathrm{third} \mathrm{cut} \mathrm{from} \mathrm{the} \mathrm{slaskie}$ voivodeship met feeding standards for ruminants.

The detected high concentration of crude fibre in feeds is characteristic for grasses at the end of earing and beginning of flowering stage, it also indicates that the meadows were mowed at a later date than regarded as optimal. Crude fat content (determined as ether extract) in bulky feeds ranges from 20 to $50 \mathrm{~g} / \mathrm{kg} \mathrm{d.m}$. [10]. Content of organic acids is an important factor deciding on the quality of silages and their suitability in animal feeding. Low acetic acid content (below $4.2 \mathrm{~g} / \mathrm{kg}$ d.m.) was obtained in [16-18] as well as Gao et al. [19] in silages with high dry matter content (499-724 g/kg d.m.).

\section{Conclusion}

The carried out chemical analyses of silages showed that in overall assessment this material was characterized of good quality; silages prepared from meadow sward from the third cut had the highest value.

The quality of silages from permanent meadows depends not only on species composition of the sward, but also on pratotechnique works, intensity of use, development 
stage at harvest time, technology of harvest and preservation of sward, and also on meteorological conditions during preservation process.

To obtain silages of good quality, it is advisable to dry them before ensilaging and also to ensilage grass in mixtures with legume. Grass forages, due to the favourable ingredients content, determine ensilage process. Thus they are considered as a good material for silage. Grass ensilage in a mixture with legume positively affects the level of total protein and reduces the break down of water-soluble carbohydrates.

\section{References}

[1] Yitbarek MB, Tamir B. Silage additives: Review. Open J Appl Sci. 2014;4:258-74. DOI: 10.4236/ojapps.2014.45026.

[2] Mohd-Setapara SH, Abd-Talibb N, Azizb R. Review on crucial parameters of silage quality. APCBEE Procedia. 2012;3:99-103. DOI: 10.1016/j.apcbee.2012.06.053.

[3] Nkosi BD, Meeske R. Effects of ensiling totally mixed potato hash ration with or without a heterofermentative bacterial inoculant on silage fermentation, aerobic stability, growth performance and digestibility in lambs. Anim Feed Sci Technol. 2010;161:38-48. DOI: 10.1016/j.anifeedsci.2010.07.015.

[4] Lynch JP, O'Kiely P, Waters SM, Doyle EM. Conservation characteristics of corn ears and stover ensiled with the addition of Lactobacillus plantarum MTD-1, Lactobacillus plantarum 30114, or Lactobacillus buchneri 11A44. J Dairy Sci. 2012;95(4):2070-80. DOI: 10.3168/jds.2011-5013.

[5] Glavić M, Toromanovi S, Zenunović A. The quality of grass silage and haylage on farms in Bosnia and Herzegovina. Agroznanje. 2013;14(1):115-22. DOI: 10.7251/AGREN1301115G.

[6] Kung Jr L, Shaver RD, Grant RJ, Schmidt RJ. Silage review: Interpretation of chemical, microbial, and organoleptic components of silages. J Dairy Sci. 2018;101(5):4020-33. DOI:10.3168/jds.2017-13909.

[7] König W, König E, Elo K, Vanhatalo A, Jaakkola S. Effects of sodium nitrite treatment on the fermentation quality of red clover-grass silage harvested at two dry matter concentrations and inoculated with clostridia. Agric Food Sci. 2019;28(4):155-64. DOI: 10.23986/afsci.85114.

[8] Pereira GA, Santos EM, Araújo GGL, Oliveira JS, Pinho RMA, de M. Zanine A, et al. Isolation and identification of lactic acid bacteria in fresh plants and in silage from Opuntia and their effects on the fermentation and aerobic stability of silage. J Agric Sci. 2019;157(9-10):684-92. DOI: 10.1017/S0021859620000143.

[9] Wrońska-Pilarek D, Jagodziński AM, Bocianowski J, Marecik M, Janyszek-Sołtysiak M. Pollen morphology and variability of Sambucus nigra L. - Adoxaceae. Biologia. 2020;75:481-93. DOI: 10.2478/s11756-019-00396-8.

[10] Ghavipanje N, Fathi Nasri MH, Farhangfar H, Modaresi J. In situ, in vitro and in vivo nutritive value assessment of Barberry leaf as a roughage for goat feeding. Small Ruminant Res. 2016;141:94-8. DOI: 10.1016/j.smallrumres.2016.07.004.

[11] Haigh PM. A note of the relationship between oven and toluene determined dry matter concentrations in big-bale grass silages. Irish J Agr Food Res. 1995;63(1):189-91. https://www.jstor.org/stable/25562260?seq=1.

[12] Haigh PM. Effluent production from grass silages treated with additives and made in large-scale bunker silos. Grass Forage Sci. 1999;54:208-18. DOI: 10.1046/j.1365-2494.1999.00172.x.

[13] Lüscher A, Mueller-Harvey I, Soussana JF, Rees RM, Peyraud JL. Potential of legume-based grassland-livestock systems in Europe: a review. Grass and Forage Sci. 2014;69(2):206-28. DOI: 10.1111/gfs.12124.

[14] Simić A, Bijelić Z, Mandić V, Sokolović D, Babić S. Permanent and sown grasslands in Serbia: current state and trends. Ann University of Craiova - Agr Montanology, Cadastre S. 2019;49(1):244-53. http://anale.agro-craiova.ro/index.php/aamc/article/viewFile/947/895.

[15] Radkowski A, Radkowska I, Bocianowski J. Effect of fertilization of meadow sward with amino acids obtained from enzymatic hydrolysis on silage quality. J Elementol. 2020;25(1):259-77. DOI: 10.5601/jelem.2019.24.3.1890.

[16] Li F, Ke W, Ding Z, Bai J, Zhang Y, Xu D, et al. Pretreatment of Pennisetum sinese silages with ferulic acid esterase-producing lactic acid bacteria and cellulase at two dry matter contents: Fermentation characteristics, carbohydrates composition and enzymatic saccharification. Bioresour Technol. 2020;395:122261. DOI: 10.1016/j.biortech.2019.122261. 
[17] Wu B, Qin H, Yang Y, Duan G, Yang S, Xin F, et al. Engineered Zymomonas mobilis tolerant to acetic acid and low $\mathrm{pH}$ via multiplex atmospheric and room temperature plasma mutagenesis. Biotechnol Biofuels. 2019;12:10. DOI: 10.1186/s13068-018-1348-9.

[18] Zhang Z, Hu X, Gao G, Wei T, Dong D, Wang Y, et al. Steam reforming of acetic acid over $\mathrm{NiKOH} / \mathrm{Al}_{2} \mathrm{O}_{3}$ catalyst with low nickel loading: The remarkable promotional effects of $\mathrm{KOH}$ on activity. Int $\mathrm{J}$ Hydrogen Energy. 2019;44(2):729-47. DOI: 10.1016/j.ijhydene.2018.10.244.

[19] Gao R, Li Z, Zhou X, Bao X, Cheng S, Zheng L. Enhanced lipid production by Yarrowia lipolytica cultured with synthetic and waste-derived high-content volatile fatty acids under alkaline conditions. Biotechnol Biofuels. 2020;13:3. DOI: 10.1186/s13068-019-1645-y. 